\title{
A review of mechanical behavior of structural laminated bamboo lumber
}

\author{
Assima Dauletbek ${ }^{\mathrm{a}, \mathrm{b}}$, Haitao $\mathrm{Li}^{\mathrm{a}, \mathrm{b}, *}$, Zhenhua Xiong $^{\mathrm{c}}$, Rodolfo Lorenzo ${ }^{\mathrm{d}}$ \\ ${ }^{a}$ College of Civil Engineering, Nanjing Forestry University, Nanjing 210037, China. \\ bJoint International Research Laboratory for Bio-composite Building Materials and Structures, Nanjing Forestry University, \\ Nanjing 210037, China. \\ ${ }^{c}$ Ganzhou Sentai bamboo company LTD, Ganzhou 341001, China. \\ ${ }^{\mathrm{d}}$ University College London, London WC1E 6BT, UK. \\ *Corresponding Author: Haitao Li. Email: 1haitao1982@126.com.
}

\begin{abstract}
The transition of the construction sector to sustainable development mostly depends on the environmental friendliness of building materials. This, in turn, calls for the development of new, strong, and sustainable materials that would be a worthy alternative for traditional materials, including wood. Over the past decade, laminated bamboo lumber (LBL) has received much attention from engineers, practitioners, and scientists for its attractive mechanical properties, comparable to and in some cases superior to hard and softwood. Moreover, the sustainability of LBL is characterized by its high carbon sequestration, fast time to harvest, high yield, and low energy consumption for processing. However, the behavior of LBL is not yet fully understood, which in turn affects the low awareness and application of the material by practitioners and engineers around the world. Since LBL has a promising future, this article will contribute to a better understanding of its mechanical properties and a more accurate design, taking into account the influencing factors. This article discusses the mechanical properties of three types of structural LBL, namely beams, columns, and sheathing panels. The previous works of researchers on the mechanical properties of structural LBL were reviewed, and thus the most common failure modes, the causes of the destruction of structural elements, and the factors that affect their behavior were discussed and described. This work will serve as a reference for current practitioners and future research.
\end{abstract}

Keywords: Laminated bamboo lumber; mechanical properties; column; beam; shear wall

\section{Introduction}

Currently, interest in bamboo as a building material is growing due to its sustainable characteristics [1-6]. Compared to wood, bamboo can grow up to 30 meters in 4 months and reach maximum strength in 3-8 years, which ensures fast and high yield [7-10]. According to life-cycle assessment (LCA) results, bamboo has the highest carbon sequestration than wood and requires less energy for processing, which reduces its environmental impact compared to traditional building materials [10,11].

Since ancient times, bamboo has been used in many areas of human life, from household utensils to the construction of houses and bridges, due to its high earthquake resistance [12], as well as its 
distinctive mechanical properties, comparable to mild steel, cast iron, aluminum alloys, and wood [1315]. For instance, the tensile strength and modulus of elasticity parallel to the grain of Moso bamboo (Phyllostachys pubescens) can reach up to $309 \mathrm{MPa}$ and $27.397 \mathrm{GPa}$, respectively [16]. Bamboo also copes well with bending loads due to a large ratio of moment of inertia to a cross-sectional area [10]. Over the past decades, new engineering bamboo materials have been developed, such as laminated bamboo lumber (LBL), glued laminated bamboo (glubam), parallel strand bamboo (PSB), etc. so it became possible to use bamboo in various shapes, sizes and applications [17, 18]. According to previous studies, the physical and mechanical properties of engineered bamboo, as well as its sustainability and flexibility, are comparable to timber and glue-laminated timber products [19-23]. For example, building weight reduction can be achieved by using composites made of bamboo and steel or bamboo and concrete; glubam panels with mineral wool increase fire resistance; and the use of bamboo structures reduces energy consumption by $65 \%$ [12]. Recently, the use of LBL in the construction of buildings and structures has increased. For example, a private villa in Saudi Arabia (Fig. 1a) and a number of structures in China were constructed using LBL as structural and facing material (Fig. 1b-d).

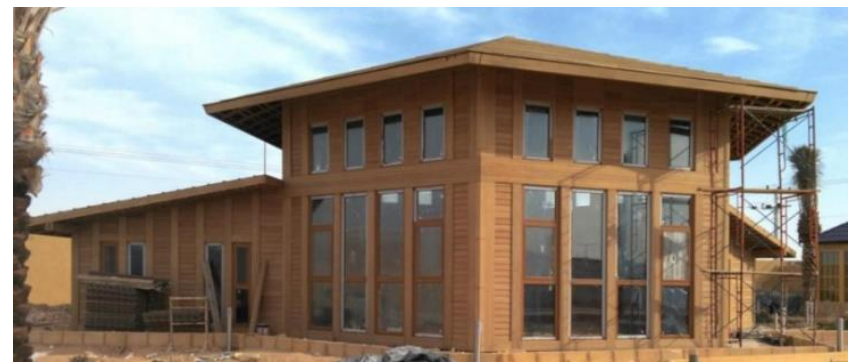

(a) Private villa in Saudi Arabia (Zhenhua Xiong)

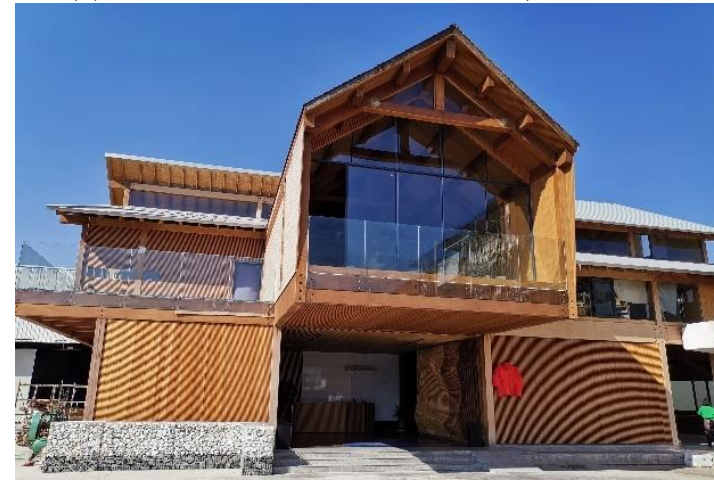

(c) Sentai office building in Ganzhou (Haitao Li)

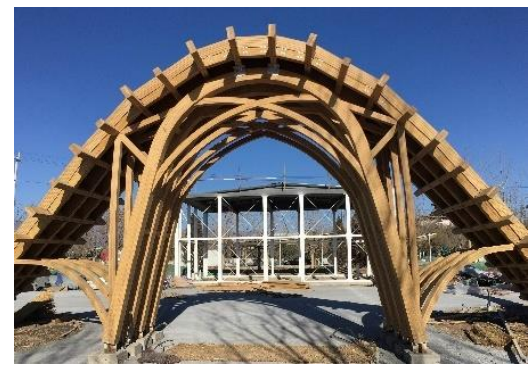

(b) Art exposition in Beijing (Zhenhua Xiong)

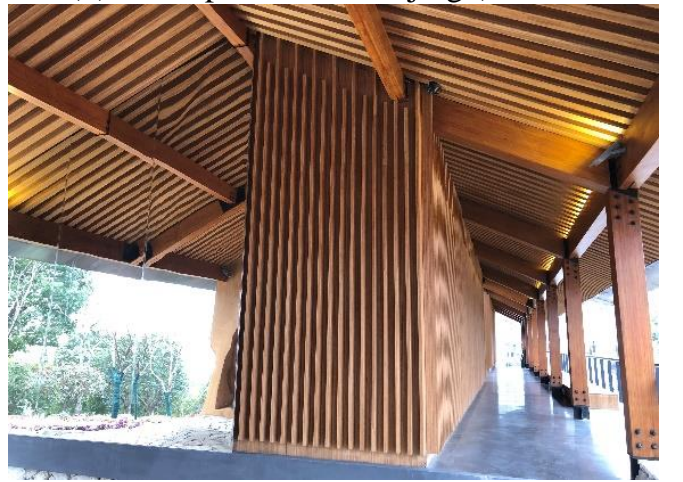

(d) Zidong Pioneer Park in Nanjing (Zhenhua Xiong)

Fig. 1. Structures made of LBL.

Extensive research has been done to determine the feasibility of LBL in structural applications, such as beams to columns and other connections [24-30]. The state of the art in LBL and bamboo scrimber development was summarized and compared to structural timber and laminated veneer lumber (LVL) [31]. International codes for timber were investigated to consider the development of allencompassing bamboo standards and building codes [32]. Technologies of full culm bamboo joints [33,34] and connections of engineered bamboo [35] were reviewed, application challenges and future research potentials were discussed.

This study aims to present a review of the mechanical performance of structural LBL such as beams, columns, and shear walls. Journals and conference articles were accepted for review, while book chapters, letters, notes, and short communications were excluded from the search according to the requirements. The requirements ensuring the consistency are: (1) an article is written in English; (2) published in a journal or conference proceedings; (3) include experimental, analytical, or numerical investigation; (4) the main focus of the article is to explore the mechanical behavior of structural LBL. According to Science Direct, there were 278, 153, and 174 research articles on "laminated bamboo beam", "laminated bamboo column", and "laminated bamboo shear wall", respectively (Fig. 2).

As can be seen from Fig. 2, since 2006, there has been a growing trend in the development of engineered bamboo materials. Since 2011, there has been a sharp increase in research, indicating a high 
demand for engineered bamboo materials in Architecture, Engineering, and Construction (AEC) industry. This leap is associated with the transition of the world economy and the AEC sector to a sustainable path, which in turn gave an impetus to the development of environmentally friendly, energyefficient, and strong alternatives to traditional building materials.

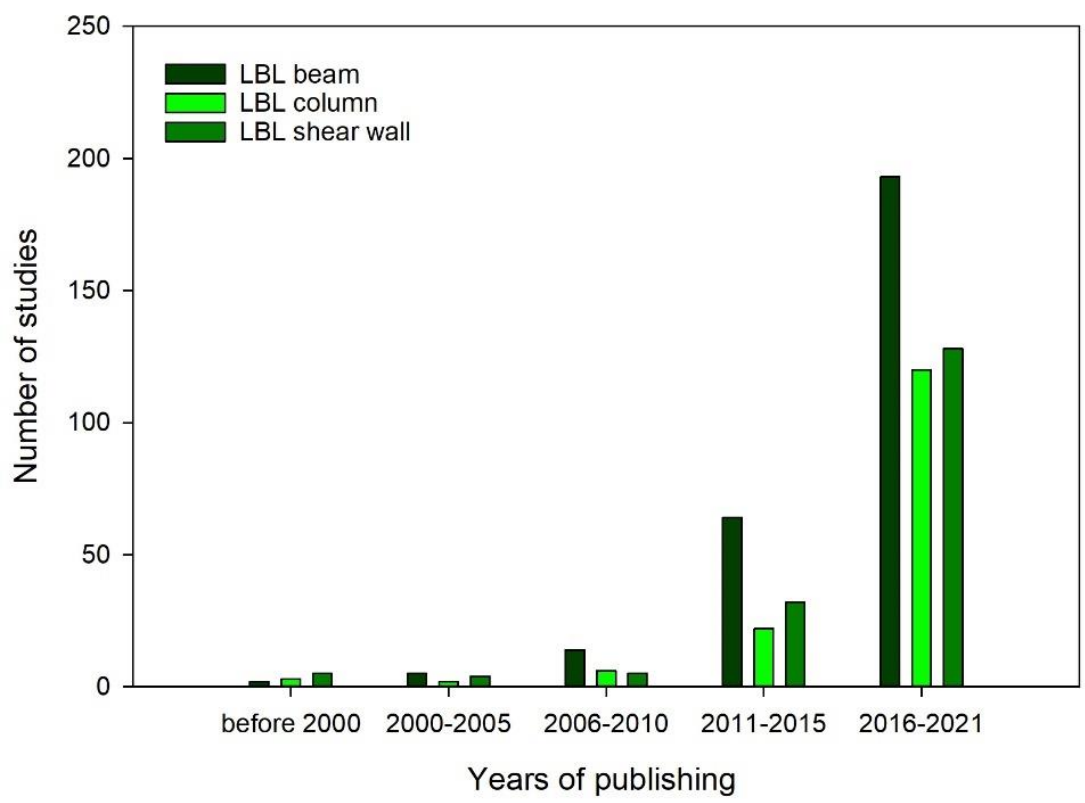

Fig. 2. Existing research on structural LBL per year via Science Direct.

Table 1. Summary of selected studies on structural LBL

\begin{tabular}{|c|c|c|c|c|c|c|}
\hline Study & Species & Glue & $\begin{array}{l}\text { The spread } \\
\text { rate, } \mathrm{g} / \mathrm{m}^{2}\end{array}$ & $\begin{array}{c}\text { Lamination } \\
\text { method }\end{array}$ & Standard & Size, $\mathrm{mm}$ \\
\hline Li et al. [36] & $\begin{array}{c}\text { Phyllostachys } \\
\text { pubescens }\end{array}$ & $\mathrm{PF}$ & 300 & - & - & $56 \times 110 \times 1950$ \\
\hline $\begin{array}{c}\text { Jorissen et al. } \\
\text { [37] }\end{array}$ & $\begin{array}{l}\text { Phyllostachys } \\
\text { pubescens }\end{array}$ & - & - & - & - & - \\
\hline $\begin{array}{c}\text { Correal et al. } \\
{[38]}\end{array}$ & $\begin{array}{c}\text { Guadua } \\
\text { Angustifolia kunt }\end{array}$ & - & - & - & - & - \\
\hline Lei et al. [39] & $\begin{array}{l}\text { Phyllostachys } \\
\text { pubescens }\end{array}$ & - & - & Hot press & $\begin{array}{c}\text { ASTM D198 } \\
\text { GB/T 50329-2012 }\end{array}$ & $\begin{array}{c}40 \text { to } \\
80 \times 120 \times 2300 \\
60 / 80 \times 120 \times 1150\end{array}$ \\
\hline Li et al. [40] & $\begin{array}{l}\text { Phyllostachys } \\
\text { pubescens }\end{array}$ & $\mathrm{PF}$ & - & - & $\begin{array}{c}\text { ASTM D198 } \\
\text { GB/T 50329-2012 }\end{array}$ & $\begin{array}{c}45 \text { to } \\
80 \times 100 \times 2400\end{array}$ \\
\hline Su et al. [41] & $\begin{array}{l}\text { Phyllostachys } \\
\text { pubescens }\end{array}$ & - & - & - & $\begin{array}{c}\text { GB 50005-2003 } \\
\text { JG/T 199-2007 } \\
\text { ASTM D143 }\end{array}$ & $80 \times 160 \times 2200$ \\
\hline $\begin{array}{c}\text { Karyadi et al. } \\
\text { [42] }\end{array}$ & $\begin{array}{l}\text { Malang, East } \\
\text { Java, Indonesia }\end{array}$ & UF & 268 & $\begin{array}{l}\text { Cold } \\
\text { clamped } \\
\text { pressure }\end{array}$ & ASTM D198 & $\begin{array}{c}89 \times 89 \times 3000 \\
79 \times 79 \times 3000 \\
71 \times 107 \times 3000 \\
65 \times 113 \times 3000 \\
65 \times 98 \times 3000 \\
67 \times 100 \times 3000 \\
71 \times 107 \times 3000 \\
80 \times 120 \times 3000\end{array}$ \\
\hline $\begin{array}{c}\text { Zhou et al. } \\
\text { [43] }\end{array}$ & $\begin{array}{l}\text { Phyllostachys } \\
\text { pubescens }\end{array}$ & $\mathrm{PF}$ & - & - & $\begin{array}{l}\text { ASTM D143 } \\
\text { ASTM D198 }\end{array}$ & $80 \times 160 \times 2100$ \\
\hline $\begin{array}{l}\text { Mujiman et } \\
\text { al. [44] }\end{array}$ & $\begin{array}{l}\text { Dendrocalamus } \\
\text { asper }\end{array}$ & PVA & - & $\begin{array}{l}\text { Cold } \\
\text { pressure }\end{array}$ & - & $\begin{array}{c}70 \times 100 \times 900 \\
70 \times 100 \times 2850\end{array}$ \\
\hline $\begin{array}{l}\text { Penellum et } \\
\text { al. [45] }\end{array}$ & $\begin{array}{l}\text { Phyllostachys } \\
\text { pubescens }\end{array}$ & PUR & 180 & $\begin{array}{l}\text { Manual } \\
\text { clamping } \\
\text { pressure }\end{array}$ & BS EN 408 & $60 \times 120 \times 2400$ \\
\hline
\end{tabular}




\begin{tabular}{|c|c|c|c|c|c|c|}
\hline Li et al. [46] & $\begin{array}{c}\text { Phyllostachys } \\
\text { pubescens }\end{array}$ & $\mathrm{PF}$ & - & $\begin{array}{c}\text { Hot } \\
\text { pressure }\end{array}$ & - & $73 \times 73 \times 1000$ \\
\hline Li et al. [47] & $\begin{array}{l}\text { Phyllostachys } \\
\text { pubescens }\end{array}$ & - & - & - & - & $100 \times 100 \times 1200$ \\
\hline Li et al. [48] & $\begin{array}{c}\text { Phyllostachys } \\
\text { pubescens }\end{array}$ & $\mathrm{PF}$ & - & $\begin{array}{c}\text { Hot } \\
\text { pressure }\end{array}$ & - & $\begin{array}{c}80 \times 80 \times 850 \text { to } \\
1700\end{array}$ \\
\hline Li et al. [49] & $\begin{array}{l}\text { Phyllostachys } \\
\text { pubescens }\end{array}$ & $\mathrm{PF}$ & - & $\begin{array}{c}\text { Hot } \\
\text { pressure }\end{array}$ & - & $\begin{array}{c}100 \times 100 \times 400 \\
\text { to } 1800\end{array}$ \\
\hline $\begin{array}{l}\text { Luna et al. } \\
\text { [50] }\end{array}$ & $\begin{array}{c}\text { Guadua } \\
\text { Angustifolia kunt }\end{array}$ & $\begin{array}{l}\text { MUF } \\
\text { PF }\end{array}$ & - & $\begin{array}{c}\text { Cold } \\
\text { pressure }\end{array}$ & $\begin{array}{l}\text { ISO } 22156 \\
\text { ISO } 22157\end{array}$ & $\begin{array}{c}50 \times 50 \times 150 \text { to } \\
1250 \\
100 \times 100 \times 250 \text { to } \\
2500\end{array}$ \\
\hline $\begin{array}{c}\text { Sharma et al. } \\
\text { [23] }\end{array}$ & $\begin{array}{c}\text { Phyllostachys } \\
\text { pubescens }\end{array}$ & $\mathrm{PF}$ & - & - & $\begin{array}{c}\text { EN } 384 \\
\text { EN } 408 \\
\text { ON ISO } 13061\end{array}$ & $\begin{array}{c}90 \times 140 \times 540 \\
45 \times 70 \times 90\end{array}$ \\
\hline $\begin{array}{l}\text { Wang et al. } \\
\text { [51] }\end{array}$ & $\begin{array}{l}\text { Phyllostachys } \\
\text { pubescens }\end{array}$ & $\mathrm{PF}$ & - & $\begin{array}{c}\text { Hot } \\
\text { pressure }\end{array}$ & - & $76 \times 76 \times 800$ \\
\hline Li et al. [52] & $\begin{array}{c}\text { Phyllostachys } \\
\text { pubescens }\end{array}$ & $\mathrm{PF}$ & - & - & ASTM D198 & $100 \times 100 \times 1200$ \\
\hline $\begin{array}{c}\text { Correal et al. } \\
{[53]}\end{array}$ & $\begin{array}{c}\text { Guadua } \\
\text { Angustifolia kunt }\end{array}$ & - & - & - & $\begin{array}{c}\text { ASTM E72 } \\
\text { ASTM E564 } \\
\text { ASTM E2126 }\end{array}$ & $2400 \times 1200$ \\
\hline $\begin{array}{c}\text { Varela et al. } \\
\text { [54] }\end{array}$ & $\begin{array}{c}\text { Guadua } \\
\text { Angustifolia kunt }\end{array}$ & $\begin{array}{l}\mathrm{MF} \\
\mathrm{UF}\end{array}$ & - & $\begin{array}{c}\text { Cold } \\
\text { pressure }\end{array}$ & $\begin{array}{l}\text { ASTM D3043 } \\
\text { ASTM E564 } \\
\text { ASTM E2126 }\end{array}$ & $9 \times 1200 \times 2400$ \\
\hline $\begin{array}{c}\text { Luna et al. } \\
{[55]}\end{array}$ & $\begin{array}{c}\text { Guadua } \\
\text { Angustifolia }\end{array}$ & - & - & - & $\begin{array}{c}\text { NTC5525 } \\
\text { NSR-10 }\end{array}$ & $15 \times 200 \times 1300$ \\
\hline
\end{tabular}

Adhesives: PF - phenol-formaldehyde, UF - urea-formaldehyde, MF - melamine-formaldehyde, PVA - polyvinyl acetate, MUF - melamine-urea-formaldehyde, PUR - polyurethane, EPI - polymerisocyanate.

Finally, 21 papers were adopted for review, from which 20 papers are published in the last 10 years, and 1 paper is of the 2007 year. It should be mentioned, that only studies that focus on the mechanical properties of structural LBL namely beams, columns, and shear walls were selected for review. Tab. 1 shows a summary of selected papers.

\section{Production}

Given the details of the literature reviewed, most studies have been done on structural LBL created from bamboo genus Phyllostachys, and only a few from Guadua and Dendrocalamus. According to previous studies [56-58], the species of bamboo affect the mechanical properties of the material, therefore, investigation of the mechanical behavior of structural LBL from equally popular bamboo genera like Bambusa and Gigantochloa is relevant.

In the literature, there are several methods of producing base bamboo material, such as dividing bamboo culm into two halves followed by flattening [31], dividing bamboo culm into grooves followed by flattening [59,60], roller flattening [61], dividing bamboo culm into grooves followed by complete separation into strips using a hammer [62], and dividing bamboo culm into strips followed by planing to obtain the uniform size. It should be noted that the flattening process is carried out at a pressure of $690 \mathrm{kPa}$ for 1-4 min [10] and it can cause cracks in the base bamboo sheet [63], so the optimization of this method is a relevant topic.

Among the manufacturing countries, China is the leader in the production and supply of bamboo building materials. Fig. 3 briefly shows the process of manufacturing LBL in China.

For the production of LBL in China, 4-5-year-old bamboo culms are chosen and divided into strips. The strips are dried till the moisture content gets $8-12 \%$ and then planed to remove wax and silica from both sides and achieve a uniform size of the strips. The strips are then treated with carbonization or bleaching. Carbonization is the placement of strips in a chamber under a pressure of $120-130^{\circ} \mathrm{C}$ to 
caramelize sugar and obtain a deep brown shade of the material [64]. Bleaching consists of placing bamboo strips in a solution of hydrogen peroxide at a temperature of $70-80^{\circ} \mathrm{C}$ [64]. According to previous research $[64,65]$, both processing methods have an impact on the mechanical properties of the LBL, so this should be taken into account when determining the structural application of the final material. After processing, the strips are folded, glued, and pressed using cold or hot pressing to obtain a homogeneous material of the required size. It is worth noting that during hot pressing, bamboo is densified, which leads to a denser material with improved mechanical properties.

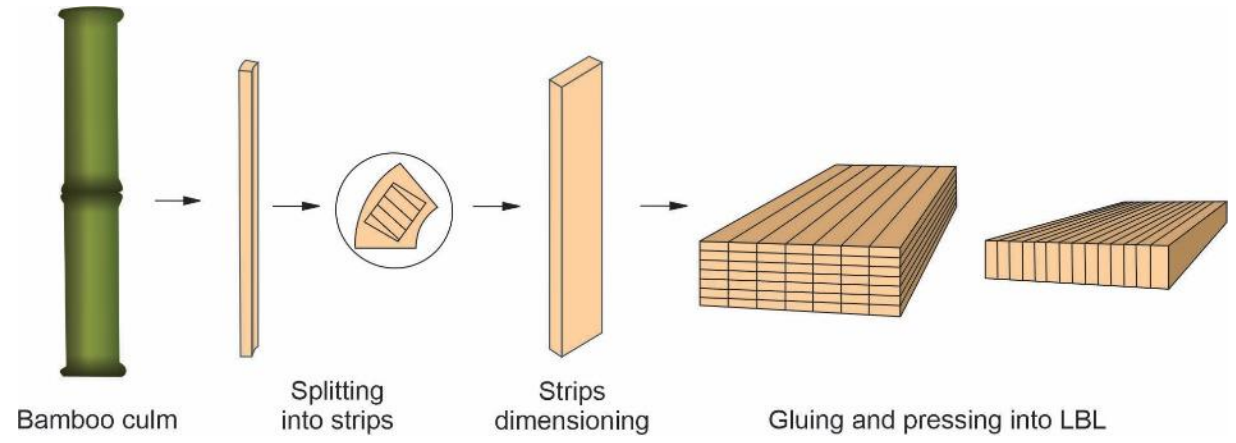

Fig. 3. The manufacturing process of LBL.

Despite the relatively low energy consumption for the production of LBL compared to conventional materials such as cement and steel, the processes of carbonization, drying, cold or hot pressing are the most harmful parts that affect the environment and make LBL more energy-intensive than wood and plywood $[12,66]$. Moreover, the use of adhesives that contain urea increases acidification and ozone depletion potentials [67]. Therefore, the development of the low-technology production of LBL is a topic of great interest. Existing studies on the environmental evaluation of LBL production and the construction of houses using engineered bamboo have not compared the potential for energy demand and other environmental indicators of LBL with the results of LCA of similar bamboo- and wood-based materials.

Based on the literature reviewed, PF is the most common adhesive used for gluing bamboo strips. It should be noted that different adhesives affect the physical and mechanical properties of LBL [6870]. According to previous studies, the specimens created with polymer-isocyanate (EPI), PUR, hybrid polymer adhesive (HPA), and PVA failed more often along the glue line than the specimens glued with MUF, as well as PF [68, 69]. At the same time, EPI appeared to be unsuitable for the creation of LBL to be used in structural applications due to delamination caused by the inability of EPI to transfer loads [68]. Generally, the amount of glue required for gluing LBL is determined by the manufacturer. Nevertheless, the glue spread rate turned out to be one of the influencing factors on the mechanical properties of small-sized LBL, so in future studies, internal bond strength should be discussed in terms of using LBL for structural purposes.

\section{Mechanical Behavior of Structural LBL}

\subsection{Beams}

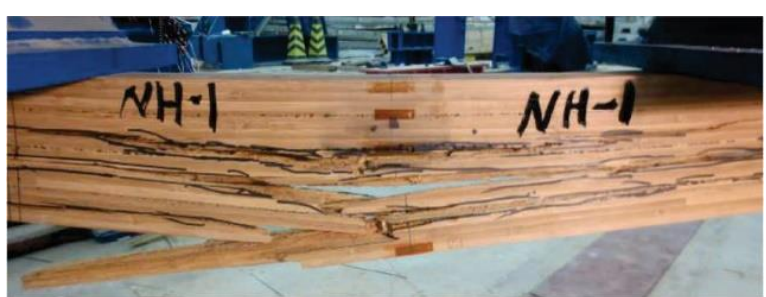

(a) Side surface

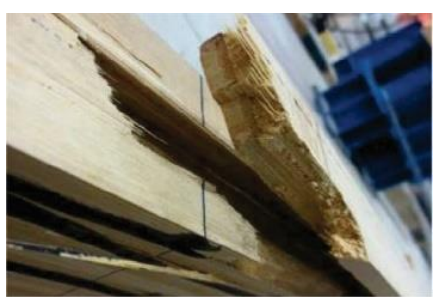

(b) Bottom surface

Fig. 4. The failure mode for the LBL beams under bending load (extracted from Li et al.'s [36] paper).

The LBL beams are structural members subjected to lateral loads, that is, forces or moments having their vectors perpendicular to the axis of the bar. During the tests, the process of destruction of the LBL beams was similar to small bending specimens and was characterized by a bottom tensile fracture (Fig. 
4).

With increasing deflection, cracks appeared on the tensile side with nodes, joints, and other defects of bamboo, since the tensile strength of bamboo was sensitive to the concentration of stresses in the area with defects [37,71]. Internal joints had more influence on specimens in tangential bending direction (TBD) than in radial bending direction (RBD) by increasing the stiffness and reducing the failure load [36], and the modulus of rupture (MOR) and modulus of elasticity (MOE) of the LBL beam with edgewise orientation were $12 \%$ and $9 \%$ higher than equivalent parameters for flatwise orientation [38]. When the deflection got very big and the outmost layer of the bamboo fiber pulled out, the beam failed due to a longitudinal splitting along the grain. The authors calculated the deflections for the ultimate load point which were more than $60 \mathrm{~mm}$ and far bigger than the value $8.4 \mathrm{~mm}(\mathrm{~L} / 250)$ prescribed as the maximum allowable deflection by the Chinese wood structure design specification (GB50005-2003). Therefore, the critical design criteria for the LBL beams should be deflection rather than strength [39].

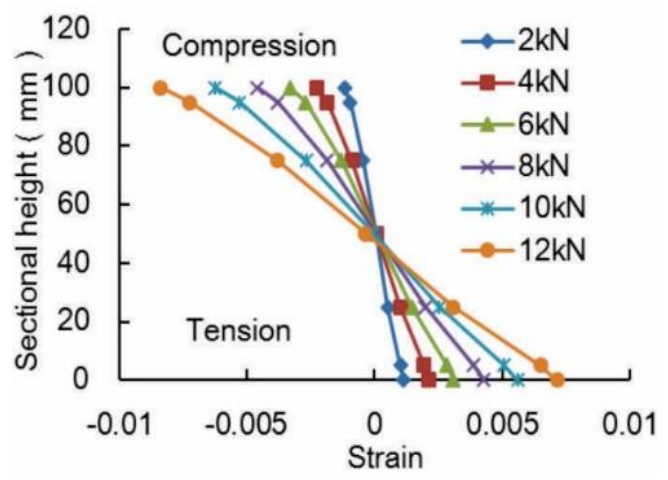

(a) Specimen LBLB45-1 (45-mm width)

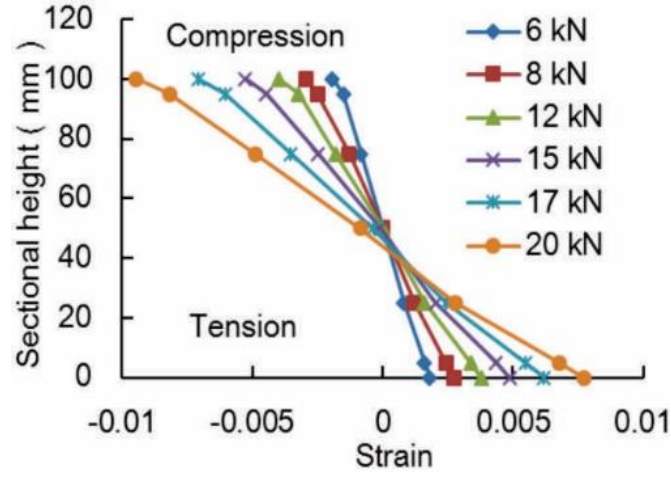

(b) Specimen LBLB70-2 (70-mm width)

Fig. 5. Typical strain profile development for the mid-span cross-section (extracted from Li et al.'s [40] paper).

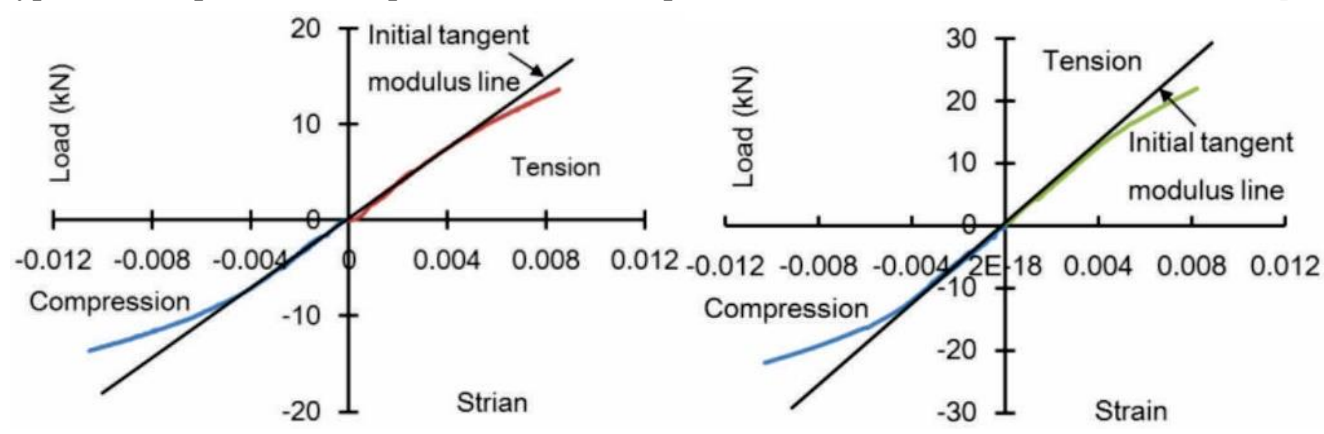

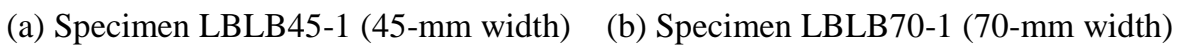

Fig. 6. Typical load-strain curves for the mid-span cross-section (extracted from Li et al.'s [40] paper).

According to previous studies, the width of the LBL beams did not affect the ultimate tensile strain, bending strength, and MOE [40], and the effect of length was insignificant. As can be seen from Fig. 5, all the strain profiles follow the same law, and the strain across the cross-section of the LBL beam was linear throughout the loading process, following the standard beam theory regardless of the length and the width of the specimen $[39,41]$.

The destruction process of the LBL beams demonstrated an initial elastic phase, non-linear deformation, and then brittle failure initiated by rupture on the tension side of the beam [40]. Fig. 6 shows the typical load against the strain for the mid-span cross-section of specimens, according to which the MOE for both the compression and the tension was equal to each other both in RBD and TBD regardless of the width of the LBL beams [36,40].

The stress was distributed linearly across the cross-section of the beams during the testing process [40], therefore the LBL beams followed the standard beam theory. Many studies proposed stress-strain relationship models for calculating the flexural capacity of LBL beams. All the models were based on similar conditions such as compliance with the plane cross-section assumption, the MOE for both compression and tension was equal, tension zone remained in a linear elastic stage, the outermost fiber 
of the tension zone reached the ultimate tensile strength, the compression zone experienced the ideal elastic-plastic state, and the stress in the plastic compression zone maintained a compressive proportional limit strength $[14,39,43]$. Based on stress-strain relationships for LBL Li, et al. [36] identified three possible failure modes of the LBL beams (Fig. 7), according to which during failure Mode 1 all bamboo fibers in the compressive zone were still in the elastic stage, while in Mode 2 some bamboo fibers in the compressive zone were in the plastic-elastic stage and some in the elastic stage, and in Mode 3, some bamboo fibers in the compressive zone were in the fully plastic stage, some in the elastic-plastic stage and some in the elastic stage.

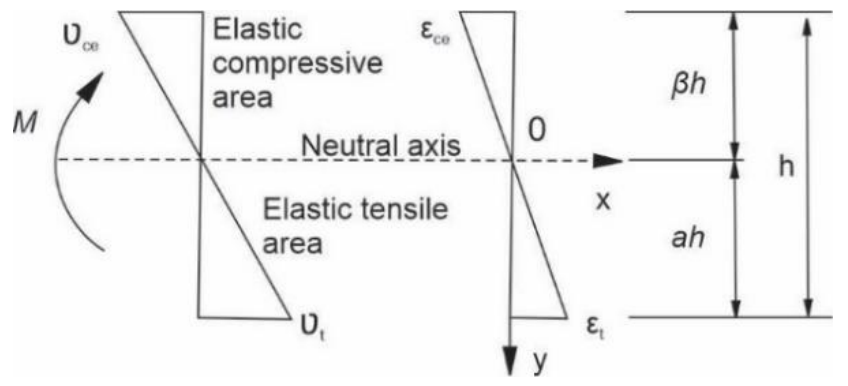

(a) Mode 1

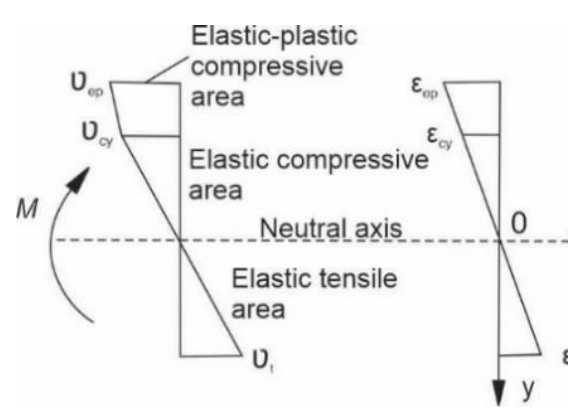

(b) Mode 2

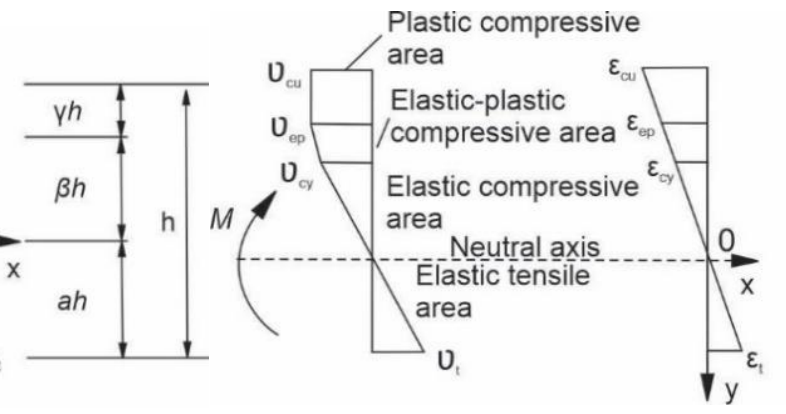

(c) Mode 3

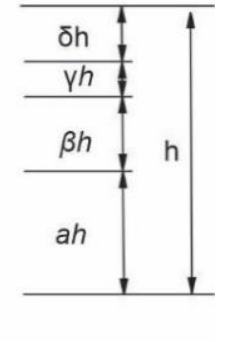

Fig.7. Strain-stress distribution at the ultimate failure state for LBL beams in different modes (reproduced according to Li et al. [36]).

Based on testing results according to full-scale structural timber standards, Sharma, et al. [23] concluded that edgewise orientation of LBL beams slightly increased bending strength and local MOE by $14 \%$ and $6-13 \%$ and constituted $61.7-66.7 \mathrm{MPa}$ and $9093-10412 \mathrm{MPa}$, respectively. While for flatwise, the same parameters were $56.6-58.6 \mathrm{MPa}$ and $8612-9178 \mathrm{MPa}$, respectively.

Karyadi and Susanto [42] compared the performance of box-section and solid beams and figured out, that the box-section beams were more efficient in receiving the transversal load compared to the solid beam for the same amount of materials, since when the ratio between the section height and section width was less or equal to 1.50 , the ability of the beam to resist the load increased proportionally with the increase of inertia moment for the same amount of material.

Mujiman, et al. [44] improved the shear and flexural strength of the LBL beams by modifying the shape of the cross-section of the lamina (curved) rather than the ordinary rectangular shape of the lamina (Fig. 8). The research results showed that in general, the LBL beams with curved lamina were more durable, rigid, and ductile compared to the beams with rectangular lamina. The average shear and bending strength of the LBL beams with the curved lamina of $7 \mathrm{~mm}$ thick were much better than that of $9 \mathrm{~mm}$ thick of curved lamina, constituting 2.72 and $68.80 \mathrm{MPa}$, respectively [44].

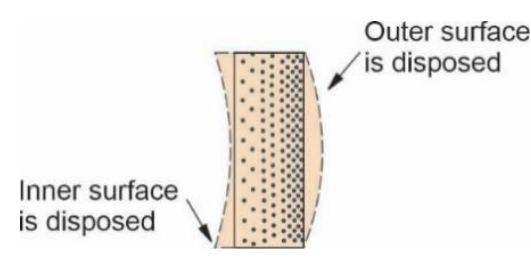

(a) Rectangular

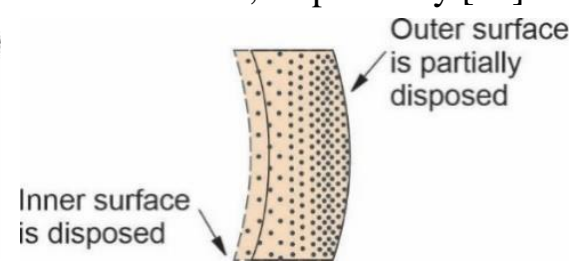

(b) Curved

Fig. 8. The disposed part of the bamboo in making the laminas [44]. 
The researchers proposed several factors as critical design criteria for calculating bamboo beams in design such as the cross-sectional stiffness [22] or deflection [39,40]. In addition, the characteristic MOE should be used for design purposes, rather than the mean [40]. Penellum, et al. [45] proposed a model of predicting the bending stiffness of LBL by "ImageJ" analysis based on "composite rule of mixtures" [45]. It should be noted, that the elastic transformed section method for the prediction of bending stiffness turned out to be ineffective and required further refinement to draw meaningful conclusions on the effect of strip orientation [45]. The work also showed that the bending stiffness variations previously attributed to solely the preservative treatment method were caused by a difference in the size of the constituent strips [45]. Zhou, et al. [43] developed the calculating models for ultimate bending moment, and ultimate bending deflections by using the progressive method in the calculation process of ultimate load-carrying capacity to trace the inelastic processes of the specimens.

Table 2. Bending performance of the LBL beams compared to similar bamboo- and wood-based beams

\begin{tabular}{|c|c|c|c|c|c|c|}
\hline Beams & Species & Size, $\mathrm{mm}$ & $\begin{array}{c}\text { Bending } \|, \\
\mathrm{MPa}\end{array}$ & $\begin{array}{l}\text { Bending } \\
\perp, \mathrm{MPa}\end{array}$ & $\begin{array}{l}\text { MOE \|, } \\
\mathrm{MPa}\end{array}$ & $\begin{array}{c}\mathrm{MOE} \perp, \\
\mathrm{MPa}\end{array}$ \\
\hline $\begin{array}{l}\text { LBL }[36, \\
39,40,42]\end{array}$ & $\begin{array}{c}\text { Phyllostachys } \\
\text { pubescens }\end{array}$ & $\begin{array}{c}56 \times 110 \times 1950 \\
40 \text { to } 80 \times 120 \times 2300 \\
60 \text { to } 80 \times 120 \times 1150 \\
45 \text { to } 80 \times 100 \times 2400 \\
79 \times 79 \times 3000 \text { to } \\
80 \times 120 \times 3000\end{array}$ & $\begin{array}{c}55.82- \\
109.73\end{array}$ & (1) & $\begin{array}{l}8730- \\
11499\end{array}$ & 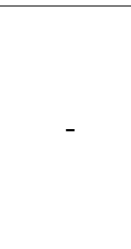 \\
\hline $\begin{array}{l}\text { Glubam } \\
{[66,72]}\end{array}$ & $\begin{array}{c}\text { Phyllostachys } \\
\text { pubescens }\end{array}$ & $\begin{array}{c}84 \times 450 \times 6000 \\
\text { to } \\
100 \times 400 \times 9000\end{array}$ & 99 & - & $\begin{array}{c}10500- \\
11200\end{array}$ & - \\
\hline LVL [73] & Heritiera spp. & $50 \times 60 \times 1080$ & 55.6 & 10.046 & 9973 & 1601.49 \\
\hline LVL [73] & Pometia spp. & $50 \times 60 \times 1080$ & 71.96 & 14.993 & 12043 & 2364.58 \\
\hline LVL [74] & Douglas-fir & - & $54.2-71.7$ & - & $\begin{array}{c}15400- \\
19300\end{array}$ & - \\
\hline $\begin{array}{c}\text { Glulam } \\
\text { [75] }\end{array}$ & Hevea brasiliensis & $20 \times 60 \times 1200$ & 75.14 & - & 8166.79 & - \\
\hline WPC [76] & Pine & - & 26.1 & 16.7 & 4100 & 2660 \\
\hline \multicolumn{2}{|c|}{ Douglas-fir [74] } & - & 85 & - & 13400 & - \\
\hline \multicolumn{2}{|c|}{ Teak [74] } & - & 80 & - & 9400 & - \\
\hline
\end{tabular}

Notes: WPC - wood plastic composite.

Tab. 2 shows the comparison of mechanical properties of the LBL beams compared to similar bamboo- and wood-based beams. As can be seen, the bending strength and MOE of the LBL beams are comparable with similar bamboo-based material glubam. The bending strength of the LBL beams can surpass those of LVL and glulam, but the MOE of the former is slightly lower than that of the latter except for glulam. According to Tab. 2, the bending performance of the LBL beams is similar to hardwoods like teak. The variability in strength values of the LBL beams can be explained by different types of adhesives, shapes of cross-section, strips orientation, the thickness of lamina, and species type used for its production.

\subsection{Columns}

Three failure modes were recorded for the LBL columns under compression along the grain: splitting, cracks extension along the compression, and propagation of the longitudinal cracks between bamboo laminates along the loading direction (Fig. 9) [46]. In both eccentric radial and tangential directions, the specimens showed the same failure modes [47].

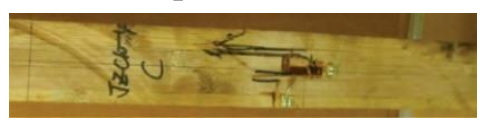

(a) Mode 1

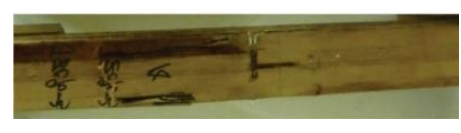

(b) Mode 2

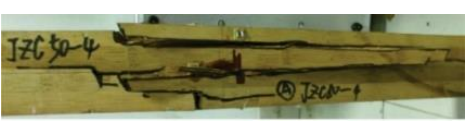

(c) Mode 3

Fig. 9. Failure modes of the LBL columns under compression (extracted from $\mathrm{Li}$, et al. [46] paper). According to Li, et al. [47], LBL columns with different heights under axial compression obtained 
2 failure modes: a squashing or crushing failure for short columns and a buckling failure for long ones. This was since the ultimate strength of long columns was less than that of the material, and the main factor affecting their load-bearing capacity was the slenderness ratio. At the same time, the load-bearing capacity of short columns was determined by the compression strength of the material. Fig. 10 shows the typical failure modes for short and long columns.

Under both tangential and radial eccentric compression directions, the strain across the crosssection of the LBL columns had similar linear properties, so they could follow the standard normal section bending theory $[46,47]$. Regardless of the lengths of the LBL columns determined by Li, et al. [48], the lateral deflection curves were close to the sine line, and the strain across the cross-section of the LBL column was linear throughout the loading process, following standard normal section bending theory.

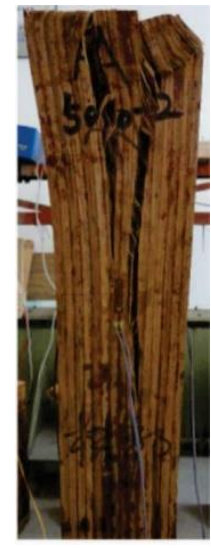

Side surface

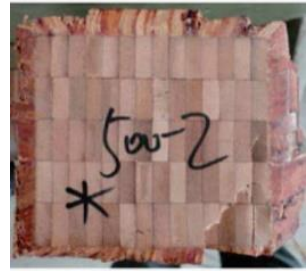

Top surface

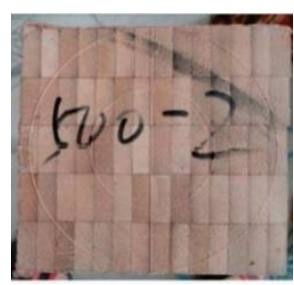

Bottom surface

(a) Short columns

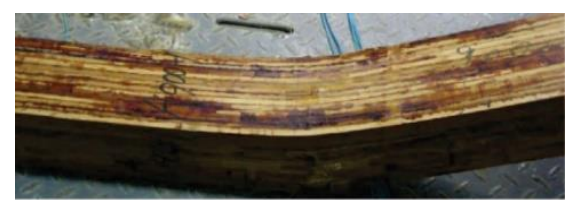

Side surface

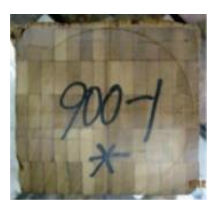

Top surface

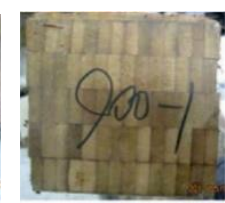

Bottom surface

(b) Long columns

Fig. 10. Failure modes of the LBL columns under compression (extracted from Li, et al. [47] paper).

Fig. $11 \mathrm{a}, \mathrm{b}$ shows the typical load-middle deflection curves for the LBL columns with different eccentricities under two eccentric directions. Initially, the specimens were in the elastic stage, followed by non-linear behavior regardless of the direction. When the peak load was reached, the lateral deflection increased and after the load was decreased, it kept growing till the failure of the specimens. It can be seen, that specimens with low eccentricity behaved plastically, while the specimens with high eccentricity showed increased lateral deflections before achieving the peak load.

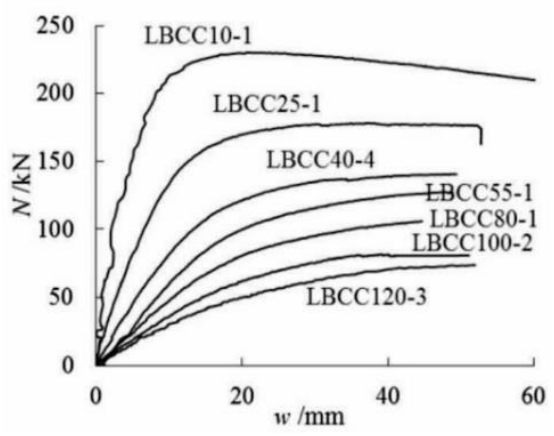

(a) Radial eccentric direction

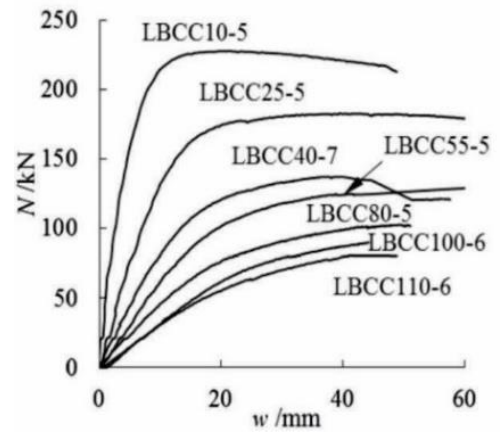

(b) Tangential eccentric direction

Fig. 11. Load-displacement curves for the LBL columns with different eccentric directions (extracted from $\mathrm{Li}$, et al. [47] paper). 
According to the results, the mechanical properties for two eccentric directions were the same, therefore, they could follow the same design rules. The authors proposed the calculation of the ultimate bearing capacity of the LBL columns by the radial eccentricity influencing coefficient $\varphi$ e, since the values of the ultimate mid-height lateral deflection and the absolute ultimate longitudinal strain increased with an increase in the eccentricity ratio [46,47]. ratios.

Fig. 12 shows the typical load-displacement curves for the LBL columns with different slenderness

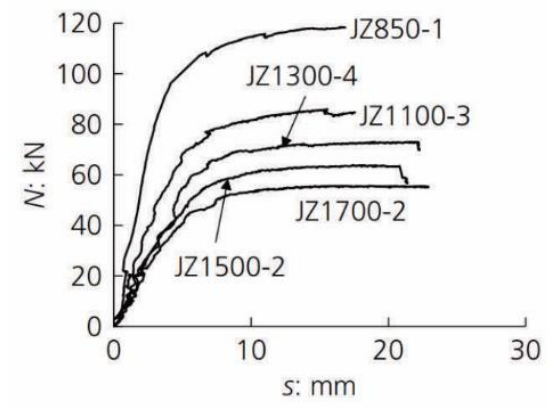

(a) Load-longitudinal displacement curves

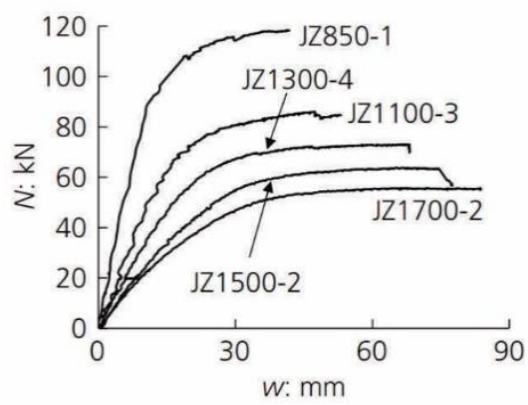

(b) Load-middle deflection curves

Fig. 12. Typical load-displacement curves comparison (extracted from Li, et al. [48] paper).

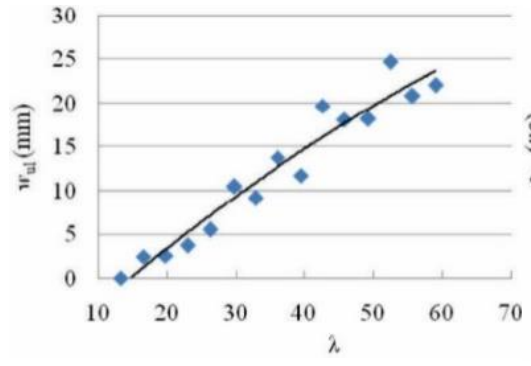

(a) Ultimate middle lateral deflection

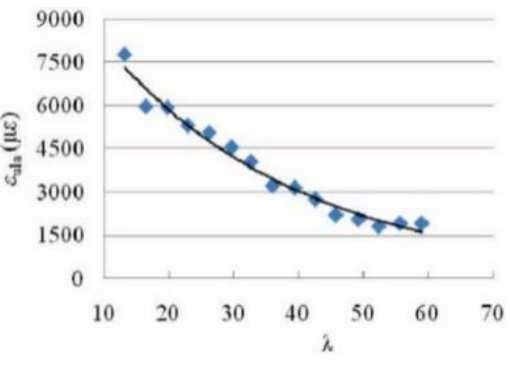

(b) Lateral strain

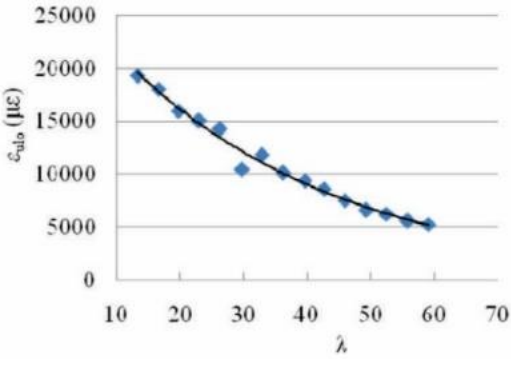

(c) Longitudinal strain

Fig. 13. Influence of slenderness ratio on the ultimate strain and deflection (extracted from $\mathrm{Li}$, et al. [49] paper).

Regardless of the length, the LBL beams showed linear behavior in the initial stage followed by non-linear, and when the peak load was achieved, both the longitudinal displacement and the lateral deflection increased with subsequent failure. The displacement was bigger in longer columns. Similarly, the values for lateral middle deflections were larger than those for longitudinal displacement. Based on the results, the authors proposed the slenderness ratio as an approach for the design of LBL columns since it affected the bearing capacity of the columns [49]. As can be seen from Fig. 13, an increase in the slenderness ratio increased the lateral deflection (Fig. 13 a) corresponding with the peak load and decreased the ultimate lateral strain (Fig. 13 b) and longitudinal strain (Fig. 13 c) [49, 50].

Based on the results of the study [49], elastic buckling theory could be applied for columns of longer length, while non-linear finite element modeling (FEM) analysis - for columns of mid and low slenderness ratios. The authors proposed the equation for the calculation of ultimate bearing capacity considering the stability coefficient $\varphi$ of LBL columns [49].

According to Sharma, et al. [23], the edgewise oriented LBL columns showed an increase in compressions strength perpendicular to grain and a decrease in local MOE, constituting $12.0-12.1$ MPa and 1197 - 1219 MPa respectively. While in compression parallel to grain, the LBL columns showed buckling failure with the bending strength and local MOE of $39.5 \mathrm{MPa}$ and $8166 \mathrm{MPa}$, respectively.

From the literature reviewed, the compression behavior of the LBL columns was characterized by elastic behavior at the beginning of loading, plastic deformation, and a decrease in the rigidity of the columns with increasing load [46-48,51]. The failure began with a tensile fracture since defects as mechanical connections or natural nodes detrimentally affected the tensile resistance of the material more than the compression [46-48,51]. And bending failure always happened for all the column 
specimens under two eccentric directions compression [48].

$\mathrm{Li}$, et al. [52] identified three failure modes of the LBL columns under compression and proposed stress-strain relationship models for each. According to the results, Mode 1 was characterized by the linear behavior of fibers both in tension and compression, and the failure happened due to the splitting of the glue (Fig. 14 a). In Mode 2, the compression zone was characterized by the elastic-plastic behavior of fibers (Fig. 14 b). And in Mode 3, the outermost compression zone achieved full plastic capacity but the remaining portion experienced elastic-plastic stress conditions at failure (Fig. $14 \mathrm{c}$ ).

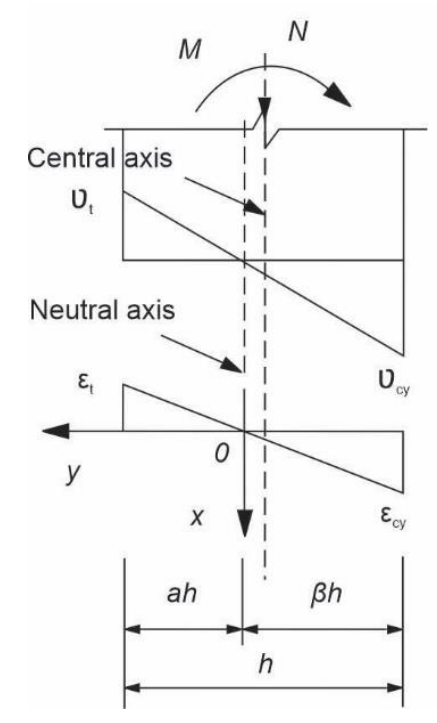

(a) Mode 1

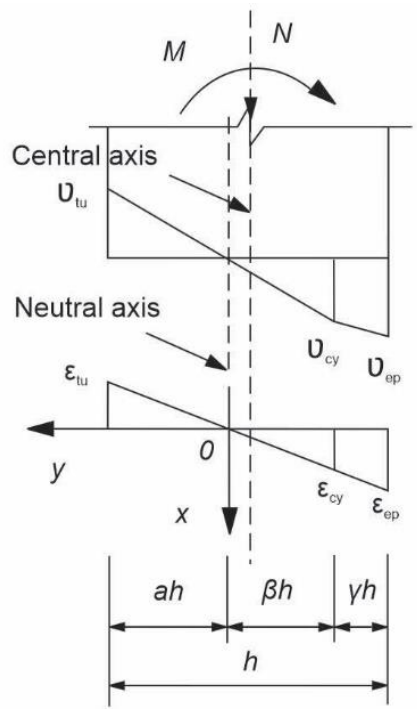

(b) Mode 2

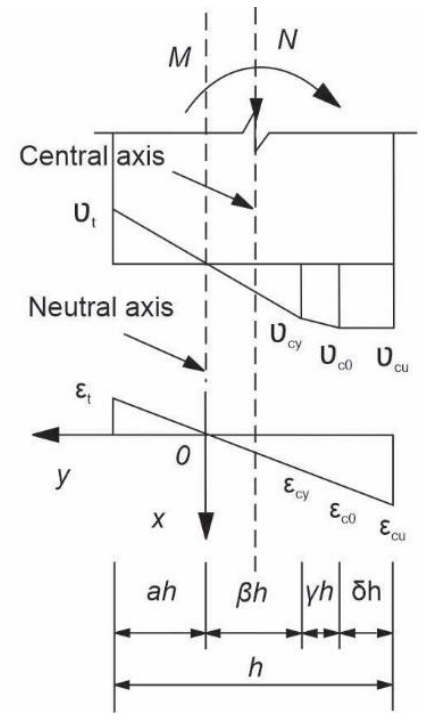

(c) Mode 3

Fig. 14. Stress-strain distribution for the LBL columns [52].

Based on a detailed analysis of failure modes of the LBL columns under eccentric compression, $\mathrm{Li}$, et al. [52] proposed equations for predicting the ultimate resistance of columns. The test results of the LBL columns under axial and eccentric compression made by Wang, et al. [51] were in good agreement with previous studies, stating that eccentricity was one of the main influencing factors for the ultimate bearing capacity of LBL columns. The results showed, that the ultimate load for the specimens with the eccentricity values of $30 \mathrm{~mm}$ and $110 \mathrm{~mm}$ decreased by $65.2 \%$ and $88.4 \%$, respectively [51]. It should be noted, that the LBL columns with box- and solid- sections under compression had an elastoplastic performance with high ductility with an average MOE for solid short columns of $5924 \mathrm{MPa}$, and a box section of $4653 \mathrm{MPa}$ [50].

When comparing the LBL columns with glulam [77] and PSB [78-80] columns, it turned out that they have similar behavior, characterized by bending brittle failure, and by the dependence of the ultimate load-bearing capacity on the slenderness ratio.

\subsection{Shear Walls}

Wooden frame buildings have good seismic resistance as their lateral systems can dissipate energy without significant loss of lateral capacity. Lateral systems are usually wooden shear walls made of a wooden frame, sheathed with wood or wood-based materials, such as (oriented strand boards) OSB, and plywood. With the development of sustainable technologies, bamboo shear walls have become a comparable eco-friendly alternative.

Previous studies compared sheathing panel materials, their aspect ratio (AR), and edge nail spacing since these factors affect the shear wall performance under lateral loads. Correal and Varela [53] examined and compared 3 building modules such as one-story module, two-story module, and twostory module with wall finish, the shear walls of which were made of LBL, OSB, and plywood. Under the shake table test, the modules exhibited light damage on the wall and the wooden frame structure without finishing, and significant cracking appeared on the corners of the windows and at the joints between the structural and non-structural walls of the exterior and interior finishing (Fig. 15).

Varela, et al. [54] compared the cyclic performance of shear walls made of LBL, OSB, and 
plywood with different edge nail spacing 2, 4, and 6 inches and wall AR 1:1 and 2:1. As shown in Fig. 16 a, the failure mode was associated with the removal of nails from the panels, although the punching of the panels with nails also took place. It is worth noting that the nail driving schedule for walls with AR 2:1 was performed in a staggered order and the nails were driven into both double end studs instead of one to improve load transfer to the end posts since monotonic and cyclic tests of shear wall with a distance between the edges of the nails 3 inches and 2 inches and AR 1:1 showed localized failure in the form of tension in the two end studs to which the clamps were attached, which in turn affected the load-displacement behavior after the peak. All cyclic tests demonstrated localized fatigue failures of sheathing nails regardless of the type of wall (Fig. $16 \mathrm{c}$ ).

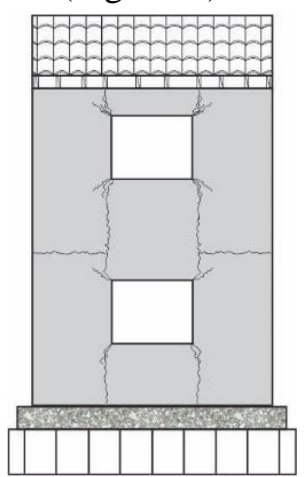

Fig. 15. Cracking pattern in exterior stucco after the tests [53].
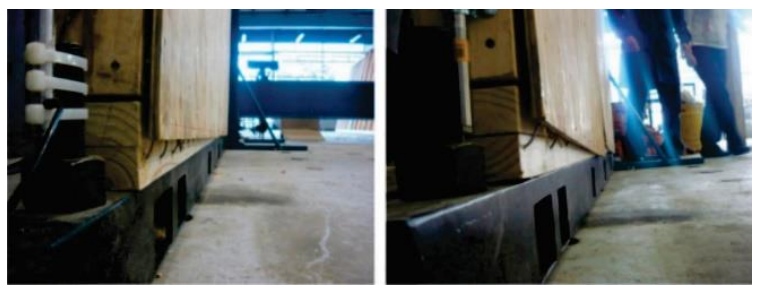

(a) Monotonic tests with LBL bamboo panels

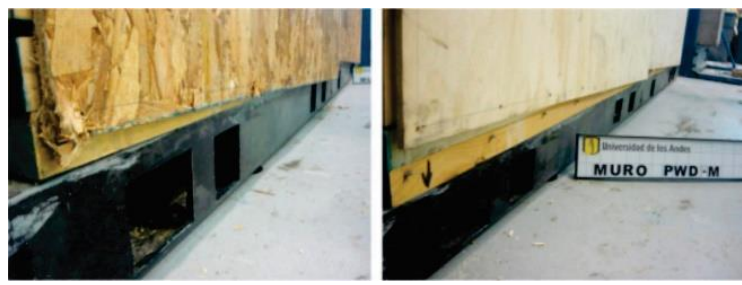

(b) Monotonic tests with OSB and plywood panels

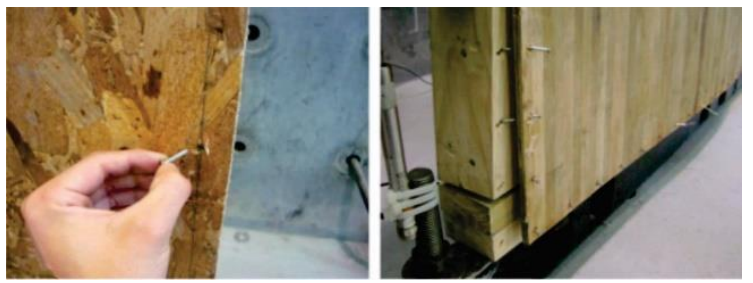

(c) Cyclic tests regardless of the type of panel

Fig. 16. Typical observed failure modes (extracted from Varela, et al. [54] paper).

At the same time, for OSB and plywood walls, tearing and punching with nails with further damage to the panel itself was observed more than for LBL walls (Fig. 16 b). This could be since the LBL panels have a higher density, which prevented the breaks and slippage that were observed in wood-based panels.

Based on the results of studies made by Correal and Varela [53] and Varela, et al. [54], it can be concluded that shear wall sheathing with LBL had similar load-displacement behavior to shear walls sheathing with OSB and plywood. Shear walls with LBL panels were affected by the edge nail spacing in the same manner as OSB and plywood. According to results, AR didn't affect peak shear strength values of the walls and energy dissipations, but an increase in the number of nails increased the strength 
of the wall. The authors recommended using adequate anchorage and force transfer details for walls with AR 1:1 and closely spaced nails due to the low capacity of the framing members. A decrease in nail spacing decreased the displacement ductility capacity and the dissipation of energy by walls, while the stiffness and maximum load-carrying capacity of the wall increased. The peak shear strength values for all panels were found to be comparable, and it is worth noting that the higher density of the LBL panels allowed them to dissipate more energy and save themselves from significant damages compared to OSB and plywood. The results of the shake table test showed limited damages on shear wall sheathing with the LBL panels after a strong earthquake simulation. According to both studies, stiffness, maximum load capacity, and ductility of the LBL sheathed shear walls were not affected by the AR of the wall. But nail spacing and sheathing panel materials had a significant effect on shear wall performance under lateral loads.

Luna and Takeuchi [55] investigated the behavior of LBL frames with K-bracing and stiffened with the LBL panels under lateral load. According to load-displacement curves obtained from the tests, frames with K-bracing exhibited elastoplastic behavior, while the elastic behavior of frames with panels was divided into two zones such as accommodation of frames and elastic region. Both structures showed that the frames had great ductility. The maximum lateral drift allowed in Colombia by the earthquakeresistant building code is $1 \%$, the value for which, the two types of structures tested were still in the elastic behavior area.

\section{Discussion}

Most of the materials from the articles reviewed were made from bamboo species Phyllostachys. Other genera of bamboo, such as Bambusa, Dendrocalamus, Gigantochloya, and Guadua can be used to create full-size LBL, and their mechanical behavior should be investigated and compared. According to the results of the review, not all types of adhesives are suitable for the production of structural LBL. The EPI appeared to be unable to transfer loads, which led to the destruction of the beam in the form of LBL delamination. In addition, past studies have pointed to the influence of adhesives types and their spread rates on the physical and mechanical characteristics of small-sized LBL, which calls for considering these influencing factors in terms of using LBL for structural purposes. Processing methods, such as carbonization and bleaching, and lamination methods, such as cold and hot pressing, also affect the physical and mechanical properties of the material and can be considered as factors determining the types of structural applications of the final product.

Despite the low environmental performance compared to conventional materials such as cement and steel, structural LBL was inferior to wood and plywood in environmental compatibility due to the highly intensive production. Moreover, the use of adhesives containing harmful substances also caused damage to the environment in the form of acidification and ozone depletion. Therefore, the development of a low-technology approach to LBL production and the use of environmentally friendly adhesives is a topic of great interest.

Currently, there are several review studies on engineering bamboo such as the basic mechanical properties of small-sized LBL, connections of the full culm bamboo and engineering bamboo, testing and design standards. However, there is not enough research on fire resistance of structural LBL, the effect of the processing methods, and fire retardant treatments on mechanical properties, as well as physical properties, such as durability, adhesion strength, dimensional stability, resistance to weather conditions, and aging.

Despite the presence of the ASTM D5456 standard, which included LBL (called laminated veneer bamboo) in the list of lumbers, the reviewed studies conducted experiments based on international and national codes used for timber. This is due to the wide demand for bamboo materials, which in turn is accompanied by a growing study of its mechanical and physical properties. The latest research results and calculation models of LBL based on wood standards should be reflected in the new editions of ASTM D5456 promptly and become the foundation for the development of a comprehensive standard for LBL.

According to the literature reviewed, the bending strength and elastic modulus parallel to grain of the LBL beam are 55.82 - 109.73 and 8730 - 11499, respectively, and resemble the behavior of hardwoods. The width and the length of the material had no effects on the behavior of the beam under 
bending, therefore, it could follow the standard beam theory. The investigators proposed 3 types of stress-strain relationships according to 3 possible failure modes of the LBL beam. The shape, thickness, and direction of the lamina affected the mechanical properties of the beam. For instance, the LBL beams with curved lamina were more durable, rigid, and ductile compared to the beams with rectangular lamina, and the specimens made of $7 \mathrm{~mm}$ thick lamina had higher bending strength than specimens with $9 \mathrm{~mm}$ thick laminas. At the same time, edgewise orientated LBL beams had slightly higher bending strength and local MOE than those of flatwise oriented beams. These influencing factors must be taken into account when producing the material for a particular end-use. Several methods for calculating the load-bearing capacity of the beam were proposed, in which the deflection of the beam was a critical design criterion.

The behavior of LBL columns was similar to that of PSB and engineered wooden columns. Under both tangential and radial eccentric compression directions, the strain across the cross-section of the LBL columns remained linear during the loading process, following the standard beam theory. The researchers developed 3 types of stress-strain relationships according to 3 possible failure modes of the LBL column. According to the results, the lamina direction had an impact on the behavior of the LBL columns under compression: the edgewise oriented LBL columns had a higher compression strength perpendicular to grain and lower local MOE. In addition, factors such as the stability coefficient, the slenderness ratio, and the eccentricity ratio affected the lateral deflection, lateral and longitudinal stresses in the columns, so they should be taken into account when calculating the bearing capacity of the columns.

Despite attractive mechanical characteristics, structural LBL also had disadvantages in the form of nodes and joints, which significantly reduced the mechanical characteristics of both beams and columns. This was because, with increasing deflection, cracks appeared on the tensile side with nodes and joints, since the tensile strength of bamboo was sensitive to the concentration of stresses in the area with defects.

The LBL panels had similar behavior to traditional OSB panels and plywood under lateral loads. Due to its density, LBL coped with energy distribution better than conventional materials, which made it the best for use in seismically hazardous areas. According to the results, the diameter of the screw and the distance between the screws and the nails significantly affected the behavior of the panels, while the influence of the aspect ratio was not observed.

\section{Conclusion}

According to the reviewed studies, LBL has great potential and can serve as a worthy alternative for conventional building materials. Even though modern research and the structural application still face the problems of high cost and high intensity of production, as well as the influence of nodes and joints on the mechanical properties, the average strength of structural LBL is similar to other bambooand wood-based materials and resembles the mechanical characteristics of hardwoods.

The mechanical properties of structural LBL were extensively studied, the most common failure modes, the causes of the destruction, and the influencing factors that correspond only to LBL were determined and discussed, which in turn will become the foundation for the development of design values for structural LBL. However, several factors still need to be addressed. The influence of bamboo species, adhesives and their spread rates, lamination methods, and clamping forces on small-sized LBL should be discussed in terms of structural applications of LBL members. Due to the growing demand for structural LBL, its modern production methods are becoming more intensive, which negatively affect the environment. Therefore, to retain the sustainability of the material, it is necessary to pay attention to low-technology and safe production with the corresponding use of environmentally friendly adhesives and reduction in energy consumption. Environmental evaluation of structural LBL based on LCA with local inventory databases and subsequent comparison with traditional materials will help in determining those production factors that need to be optimized. With the growing research interest, as well as the emergence of new bamboo-based materials, further testing based on timber standards is necessary in order to determine the properties, bamboo-based influencing factors, and create allencompassing test and design standards similar to those used for wood.

The reliability of LBL structures is determined not only by the level of safety, comfort, and compliance with sanitary, hygienic, and fire resistance requirements but also by the retention of material 
properties during a long time of operation. Therefore, the influence of processing methods and fire retardant treatments of structural LBL on its physical and mechanical properties, durability, resistance to temperature fluctuations, humidity, and aging is a topic of great interest. Also, it is necessary to study the environmental impact associated with the treatment of LBL products.

The attractive characteristics of structural LBL have been demonstrated in numerous studies. In addition to the distinctive strength, structural members made of LBL can be created in any cross-section, shape, and meet different heights and spans of structures. The high cost of LBL members may delay its widespread use in the AEC sector, but the growing research interest, the development of low-cost and sustainable production methods, and, as a result, an increase in demand, will help structural LBL become a beneficial option in the construction of public and residential buildings. With the research progress in LBL, the integration of existing results will help to create the most innovative solutions that are profitable in terms of structural applications, cost, and environmental compatibility.

\section{Funding Statement}

The research work presented in this paper is supported by the National Natural Science Foundation of China (Nos. 51878354 \& 51308301), the Natural Science Foundation of Jiangsu Province (Nos. BK20181402 \& BK20130978), Six talent peak high-level projects of Jiangsu Province (No. JZ029), and Qinglan Project of Jiangsu Higher Education Institutions. Any research results expressed in this paper are those of the writer(s) and do not necessarily reflect the views of the foundations.

\section{Conflicts of Interest}

The authors declare no conflict of interest.

\section{References}

[1] Ramirez F, Correal JF, Yamin LE, Atoche JC, Piscal CM. Dowel-bearing strength behavior of glued laminated Guadua bamboo. J Mater Civil Eng 2012; 24(11): 1378-1387. http://doi.org/10.1061/(Asce)Mt.1 943-5533.0000515.

[2] Arbelaez J, Correal J. Racking performance of traditional and non-traditional engineered bamboo shear walls. Key Eng Mater 2012; 517: 171-178. http://doi.org/10.4028/www.scientific.net/KEM.517.171.

[3] Richard M, Gottron J, Harries K, Ghavami K. Experimental evaluation of longitudinal splitting of bamboo flexural components. P I Civil Eng-Str B 2016; 170: 1-10. http://doi.org/10.1680/jstbu.16.00072.

[4] Zea Escamilla E, Archila H, Nuramo D, Trujillo D. Bamboo: an engineered alternative for buildings in the global south. Bioclimatic Architecture in Warm Climates 2019; 397-414. http://doi.org/10.1007/978-3-03012036-8_15.

[5] Harries K, Morrill P, Gauss C, Flower C, Akinbade Y, Trujillo D. Screw withdrawal capacity of full-culm P. edulis bamboo. Constr Build Mater 2019; 216: 531-541. http://doi.org/10.1016/j.conbuildmat.2019.05.009.

[6] Xiao Y, Li L, Yang RZ. Long-term loading behavior of a full-scale glubam bridge model. J Bridge Eng 2014; 19(9): 04014027. http://doi.org/10.1061/(asce)be.1943-5592.0000600.

[7] Lee AWC, Chen G, Tainter FH. Comparative treatability of Moso bamboo and Southern pine with CCA preservative using a commercial schedule. Bioresource Technol 2001; 77(1): 87-88. http://doi.org/10.1016/ S0960-8524(00)00145-0.

[8] Fang C, Jiang Z, Sun Z, Liu H, Zhang X, Zhang R, Fei B. An overview on bamboo culm flattening. Constr Build Mater 2018; 171: 65-74. http://dx.doi.org/10.1016/j.conbuildmat.2018.03.085.

[9] Khoshbakht N, Clouston P, Arwade S, Schreyer A. Computational modeling of laminated veneer bamboo dowel connections. J Mater Civil Eng 2018; 30(2): 04017285. http://doi.org/10.1061/(asce)mt.19435533.0002135

[10] Mahdavi M, Clouston P, Arwade S. Development of laminated bamboo lumber: review of processing, performance, and economical considerations. J Mater Civil Eng 2011; 23(7): 1036-1042. http://dx.doi.org/ 10.1061/(ASCE)MT.1943-5533.0000253.

[11] Zea Escamilla E, Habert G, Daza JFC, Archilla HF, Fernandez JSE, Trujillo D. Industrial or traditional bamboo construction? Comparative life cycle assessment (LCA) of bamboo-based buildings. Sustainability 2018; 10(9): 3096. http://doi.org/10.3390/su10093096.

[12] Yang G, Wang K. Evaluation on the application of GLB structures. Chem. Eng. J. 2020; 8(5): 21-37. http:// 
doi.org/10.4236/msce.2020.85003.

[13] Li Z, Chen C, Mi R, Gan W, Dai J, Jiao M, Xie H, Yao Y, Xiao S, Hu L. A strong, tough, and scalable structural material from fast-growing bamboo, Adv Mater 2020; 32(10): 1906308. http://dx.doi.org/10.1002/ adma.201906308.

[14] Huang Z, Chen Z, Huang D, Zhou A. The ultimate load-carrying capacity and deformation of laminated bamboo hollow decks: experimental investigation and inelastic analysis. Constr Build Mater 2016; 117: 190197. http://doi.org/10.1016/j.conbuildmat.2016.04.115.

[15] Jin X, Jiang Z, Wen X, Zhang R, Qin D. Flame retardant properties of laminated bamboo lumber treated with monoammonium phosphate (MAP) and boric acid/borax (SBX) compounds. Bioresources 2017; 12(3): 5071-5085

[16] Yu HQ, Jiang ZH, Hse CY, Shupe TF. Selected physical and mechanical properties of Moso bamboo (Phyllostachys Pubescens). J Trop for Sci 2008; 20(4): 258-263. http://dx.doi.org/10.15376/biores.12.3.507 1-5085.

[17] Yu Y, Huang X, Yu W. A novel process to improve yield and mechanical performance of bamboo fiberreinforced composite via mechanical treatments. Compos Part B-Eng 2014; 56: 48-53. http://doi.org/10.10 16/j.compositesb.2013.08.007.

[18] Park SH, Jang JH, Wistara Nyoman J, Hidayat W, Lee M, Febrianto F. Anatomical and physical properties of Indonesian bamboos carbonized at different temperatures. Korean J. Food Sci. Technol 2018; 46(6): 656669. http://dx.doi.org/10.5658/WOOD.2018.46.6.656.

[19] Chow A, Ramage MH, Shah DU. Optimising ply orientation in structural laminated bamboo. Constr Build Mater 2019; 212: 541-548. http://doi.org/10.1016/j.conbuildmat.2019.04.025.

[20] Deng JC, Chen FM, Li HD, Shi SQ. The effect of PF/PVAC weight ratio and ambient temperature on moisture absorption performance of bamboo-bundle laminated veneer lumber. Polym Composite 2016; 37(3): 955-962. http://doi.org/10.1002/pc.23255.

[21] Deng J, Wei X, Zhou H, Wang G, Zhang S. Inspiration from table tennis racket: preparation of rubber-woodbamboo laminated composite (RWBLC) and its response characteristics to cyclic perpendicular compressive load. Compos Struct 2020; 241: 112135. http://doi.org/10.1016/j.compstruct.2020.112135.

[22] Chen G, Yu YF, Li X, He B. Mechanical behavior of laminated bamboo lumber for structural application: an experimental investigation. Eur J Wood Wood Prod 2020; 78(1): 53-63. http://doi.org/10.1007/s00107-01901486-9.

[23] Sharma B, Bauer H, Schickhofer G, Ramage MH. Mechanical characterization of structural laminated bamboo. P I Civil Eng-Str B 2017; 170 (4): 250-264. http://doi.org/10.1680/jstbu.16.00061.

[24] Cui Z, Xu M, Tu L, Chen Z, Hui B. Determination of dowel-bearing strength of laminated bamboo at elevated temperatures 2020. J Build Eng 2020; 30: 101258. http://doi.org/10.1016/j.jobe.2020.101258.

[25] Yang RZ, Xiao Y. Experimental study of glubam single-bolted joint loaded by tension. Key Eng Mater 2012; 517: 34-42. http://doi.org/10.4028/www.scientific.net/KEM.517.34.

[26] Khoshbakht N, Clouston PL, Arwade SR, Schreyer AC. Evaluation of ASTM D5764 dowel connection tests for laminated veneer bamboo (LVB). J Test Eval 2019; 47(4): 2717-2736. http://dx.doi.org/10.1520/JTE201 80385 .

[27] Reynolds T, Sharma B, Harries K, Ramage M. Dowelled structural connections in laminated bamboo and timber. Compos Part B-Eng 2016; 90: 232-240. http://doi.org/10.1016/j.compositesb.2015.11.045

[28] Tang Z, Shan B, Li WG, Peng Q, Xiao Y. Structural behavior of glubam I-joists. Constr Build Mater 2019; 224: 292-305. http://doi.org/10.1016/j.conbuildmat.2019.07.082.

[29] Wang R, Xiao Y, Li Z. Lateral loading performance of lightweight glubam shear walls. J Struct Eng 2017; 143(6): 04017020. http://doi.org/10.1061/(asce)st.1943-541x.0001751.

[30] Wang R, Wei SQ, Li Z, et al., Performance of connection system used in lightweight glubam shear wall. Constr Build Mater 2019; 206: 419-431. http://doi.org/10.1016/j.conbuildmat.2019.02.081.

[31] Ramage M, Sharma B, Bock M, Gatóo A, Mulligan H. Engineered bamboo: State of the art. Proceedings of the ICE - Construction Materials 2015; 168: 57-67. http://doi.org/10.1680/coma.14.00020.

[32] Gatóo A, Sharma B, Bock M, Mulligan H, Ramage M. Sustainable structures: Bamboo standards and building codes. Proceedings of the ICE - Engineering Sustainability 2014; 167: 189-196. http://doi.org/10.1680/ensu.14.00009.

[33] Hong C, Lorenzo R, Wu G, Corbi I, Corbi O, Xiong Z, Yang D, Zhang H. Review on connections for original bamboo structures. J Renew Mater 2019; 7(8): 713-730. http://doi.org/10.32604/jrm.2019.07647.

[34] Disén K, Clouston P. Building with bamboo: a review of culm connection technology. J Green Build 2013; 8: 83-93. http://doi.org/10.3992/jgb.8.4.83.

[35] Hong CK, Li HT, Xiong ZH, Lorenzo R, Corbi I, Corbi O, Wei DD, Yuan CG, Yang D, Zhang HZ. Review of connections for engineered bamboo structures. J Build Eng 2020; 30: 101324. http://doi.org/10.1016/j.job e.2020.101324.

[36] Li HT, Wu G, Zhang QS, Deeks AJ, Su JW. Ultimate bending capacity evaluation of laminated bamboo 
lumber beams. Constr Build Mater 2018; 160: 365-375. http://doi.org/10.1016/j.conbuildmat.2017.11.058.

[37] Jorissen AJM, Voermans J, Jansen MH. Glued-laminated bamboo: node and joint failure in bamboo laminations in tension. J Bamboo Rattan 2007; 6(3-4): 137-144.

[38] Correal J, Echeverry J, Yamin L, Ramirez F. Experimental behavior of structural size glued laminated Guadua bamboo members. WCTE 2014.

[39] Lei J, Chen B, Yuan P. Experimental study on flexural properties of side-pressure laminated bamboo beams, Adv Civ Eng 2020; 2020: 1-10. http://doi.org/10.1155/2020/5629635.

[40] Li HT, Deeks AJ, Zhang QS, Wu G. Flexural performance of laminated bamboo lumber beams. Bioresources 2016; 11(1): 929-943.

[41] Su Y, Zong S, Xu D, Sun D, Huang D. Experimental study on nonlinear bending of glued laminated bamboo beams, Journal of Building Structures 2016; 37: 36-43. http://doi.org/10.14006/j.jzjgxb.2016.10.005.

[42] Karyadi, Susanto PB. Mechanical characteristics of box-section beam made of sliced-laminated Asian bamboo (Dendrocalamus asper) in bending failure mode under transversal load. AIP Conference Proceedings 2017; 1887. https://doi.org/10.1063/1.5003545.

[43] Zhou AP, Bian YL, Shen YR, Huang DS, Zhou MJ. Inelastic bending performances of laminated bamboo beams: experimental investigation and analytical study. Bioresources 2018; 13(1): 131-146. http://doi.org/1 0.15376/biores.13.1.131-146.

[44] Mujiman, Priyosulistyo H, Sulistyo D, Prayitno TA. Influence of shape and dimensions of lamina on shear and bending strength of vertically glue-laminated bamboo beam. Procedia Engineer 2014; 95: 22-30. http: //doi.org/10.1016/j.proeng.2014.12.161.

[45] Penellum M, Sharma B, Shah DU, Foster RM, Ramage MH. Relationship of structure and stiffness in laminated bamboo composites. Constr Build Mater 2018; 165: 241-246. http://doi.org/10.1016/j.conbuildma t.2017.12.166.

[46] Li HT, Chen G, Zhang QS, Ashraf M, Xu B, Li YJ. Mechanical properties of laminated bamboo lumber column under radial eccentric compression. Constr Build Mater 2016; 121: 644-652. http://doi.org/10.1016/ j.conbuildmat.2016.06.031.

[47] Li HT, Wu G, Zhang QS, Su JW. Mechanical evaluation for laminated bamboo lumber along two eccentric compression directions. J Wood Sci 2016; 62(6): 503-517. http://doi.org/10.1007/s10086-016-1584-1.

[48] Li HT, Liu R, Lorenzo R, Wu G, Wang LB. Eccentric compression properties of laminated bamboo columns with different slenderness ratios. P I Civil Eng-Str B 2019;172(5): 314-326. http://doi.org/10.1680/jstbu.18. 00007.

[49] Li HT, Su JW, Zhang QS, Deeks AJ, Hui D. Mechanical performance of laminated bamboo column under axial compression. Compos Part B-Eng 2015; 79: 374-382. http://doi.org/10.1016/j.compositesb.2015.04.0 27

[50] Luna P, Takeuchi C, Alvarado C, Moreno I. Glued laminated Guadua angustifolia bamboo columns, Acta Hortic 2013; 1003: 125-129. http://doi.org/10.17660/ActaHortic.2013.1003.16.

[51] Wang CW, Zhang HZ, Zhao CJ, Zhang CG, Cao TW, Dong HR, Ding JY, Xiong ZH, Xiong XH, Liu WF, Wu KW, Liu R, Ding W, Yan ZW. Experimental study on laminated bamboo lumber column, E3s Web Conf 2018; 38: 02001. http://doi.org/10.1051/e3sconf/20183802001

[52] Li HT, Su JW, Xiong ZH, Ashraf M, Corbi I, Corbi O. Evaluation on the ultimate bearing capacity for laminated bamboo lumber columns under eccentric compression. Structures 2020; 28: 1572-1579. http://doi.org/10.1016/j.istruc.2020.10.004.

[53] Correal J, Varela S. Experimental study of glued laminated Guadua bamboo panel as an alternative shear wall sheathing material. Key Eng Mater 2012; 517: 164-170. http://doi.org/10.4028/www.scientific.net/KE M.517.164.

[54] Varela S, Correal J, Yamin L, Ramirez F. Cyclic performance of glued laminated Guadua bamboo-sheathed shear walls. J Struct Eng 2013; 139 (11): 2028-2037. http://doi.org/10.1061/(Asce)St.1943-541x.0000758.

[55] Luna P, Takeuchi C. Experimental analysis of frames made with glued laminated pressed bamboo Guadua. Key Eng Mater 2012; 517: 184-188. http://doi.org/10.4028/www.scientific.net/KEM.517.184.

[56] Rosa RA, Paes JB, Segundinho PGD, Vidaurre GB, de Oliveira AKF. Influences of species, preservative treatment and adhesives on physical properties of laminated bamboo lumber. Cienc Florest 2016; 26(3): 913924.

[57] Rusch F, Trevisan R, Hillig E, Mustefaga E. Physical-mechanical properties of laminated bamboo panels. Pesqui Agropecu Trop 2019; 49. http://doi.org/10.1590/1983-40632019v4953714.

[58] Natividad R, Jimenez Jr J. Development of laminated buho [Schizostachyum lumampao (Blanco) Merr.] lumber. Philippine For Prod J 2015; 6: 79-89.

[59] Bakar ES, Nazip MNM, Anokye R, Hua LS. Comparison of three processing methods for laminated bamboo timber production. J Forestry Res 2019; 30(1): 363-369. http://doi.org/10.1007/s11676-018-0629-2.

[60] Bakar ES, Zulfa U, Maniam T. Conversion of bamboo culms into bamboo mat through V-grooving method. PRICM-8 2006. 
[61] Nugroho N, Ando N. Development of structural composite products made from bamboo II: fundamental properties of laminated bamboo lumber. J Wood Sci 2001; 47(3): 237-242. http://doi.org/10.1007/Bf01171 228.

[62] Mahdavi M, Clouston PL, Arwade SR. A low-technology approach toward fabrication of laminated bamboo lumber. Constr Build Mater 2012; 29: 257-262. http://doi.org/10.1016/j.conbuildmat.2011.10.046.

[63] Atienza AH, Gutlay H, Rodrigo P, Tamayo P. Steam integrated flattening machine for bamboo culms. IOP Conference Series: Materials Science and Engineering 2020; 739: 012027. http://doi.org/10.1088/1757899X/739/1/012027.

[64] Sharma B, Gatoo A, Ramage MH. Effect of processing methods on the mechanical properties of engineered bamboo. Constr Build Mater 2015; 83: 95-101. http://doi.org/10.1016/j.conbuildmat.2015.02.048.

[65] Reynolds TPS, Sharma B, Serrano E, Gustafsson PJ, Ramage MH. Fracture of laminated bamboo and the influence of preservative treatments. Compos Part B-Eng 2019; 174: 107017. http://doi.org/10.1016/j.comp ositesb.2019.107017.

[66] Xiao Y, Shan B, Yang RZ, Li Z, Chen J. Glue laminated bamboo (glubam) for structural applications. Rilem Bookser 2014; 9: 589-601. http://doi.org/10.1007/978-94-007-7811-5_54.

[67] Li JQ, Yuan Y, Guan X. Assessing the environmental impacts of glued-laminated bamboo based on a life cycle assessment. Bioresources 2016; 11(1): 1941-1950. http://doi.org/10.15376/biores.11.1.1941-1950.

[68] Sinha A, Way D, Mlasko S. Structural performance of glued laminated bamboo beams. J Struct Eng 2014; 140(1): 04013021. http://doi.org/10.1061/(asce)st.1943-541x.0000807.

[69] Xing W, Hao J, Sikora Karol S. Shear performance of adhesive bonding of cross-laminated bamboo. J Mater Civil Eng 2019; 31(9): 04019201. http://doi.org/10.1061/(asce)mt.1943-5533.0002854.

[70] Teixeira DE, Bastos RP, Almeida SAD. Characterization of glued laminated panels produced with strips of bamboo (Guadua Magna) native from the Brazilian Cerrado. Cerne 2015; 21(4): 595-600. http://doi.org/10. 1590/01047760201521041893.

[71] Xuan YW, Li HT, Bei ZM, Xiong ZH, Lorenzo R, Corbi I, Corbi O. Nodes effect on the bending performance of laminated bamboo lumber unit. J Renew Mater 2021; 9(6): 1143-1156. http://doi.org/10.32604/jrm.2021. 015292.

[72] Li Z, Yang GS, Zhou Q, Shan B, Xiao Y. Bending performance of glubam beams made with different processes. Adv Struct Eng 2019; 22(2): 535-546. http://doi.org/10.1177/1369433218794327.

[73] Kim T, Noh N, Bhkari N, Ahmad Z, Chen L, Harun M, Ng Ji L. Static bending performance of mengkulang and kasai lvl beam in structural size. J Phys Conf Ser 2021; 1793: 012062. http://doi.org/10.1088/1742$6596 / 1793 / 1 / 012062$.

[74] Wood Handbook (2010). Wood as an Engineering Material. USA: Department of Agriculture, Forest Service, Forest Products Laboratory.

[75] Faria D, Andrade Lopes T, Scatolino M, Soriano J, Mendes L, Guimarães J. Static bending of glulam beams manufactured with rubberwood and epoxy adhesive. Matéria 2020; 25. http://doi.org/10.1590/s1517707620200003.1104.

[76] Hugot F, Cazaurang G. Mechanical properties of an extruded wood plastic composite. Mec Ind 2009; 10(6): 519-524. http://dx.doi.org/10.1051/meca/2010010.

[77] Zhou XY, Zeng D, Wang ZF. Experimental study on mechanical properties of larch glulam columns under axial compression. Appl Mech Mater 2016; 847: 38-45. http://doi.org/10.4028/www.scientific.net/AMM.84 7.38 .

[78] Huang D, Bian Y, Huang D, Zhou A, Sheng B. An ultimate-state-based model for inelastic analysis of intermediate slenderness PSB columns under eccentrically compressive load. Constr Build Mater 2015; 94: 306-314. http://doi.org/10.1016/j.conbuildmat.2015.06.059.

[79] Wang X, Zhou A, Chui Y. Load-carrying capacity of intermediately slender parallel strand bamboo columns with a rectangular cross-section under biaxial eccentric compression. Bioresources 2018; 13: 313-330. http://dx.doi.org/10.15376/biores.13.1.313-330.

[80] Zhou K, Li HT, Hong CK, Ashraf M, Sayed U, Lorenzo R, Corbi I, Corbi O, Yang D, Zuo YF. Mechanical properties of large-scale parallel bamboo strand lumber under local compression. Constr Build Mater 2021; 271: 121572. http://doi.org/10.1016/j.conbuildmat.2020.121572. 